\title{
Improving knowledge, attitude, and practices of complementary feeding using practical intervention training for parents living in stunting villages in Central Lombok, Indonesia: A community-based study
}

Jeslyn Tengkawan ( $\sim$ jeslynteng@yahoo.com )

Yayasan Capella Project Indonesia https://orcid.org/0000-0002-8644-1872

Ayu Anandhika Septisari

Yayasan Capella Project Indonesia

Zulfikar Ihyauddin

Yayasan Capella Project Indonesia

Titi Pambudi Karuniawaty

Universitas Mataram Fakultas Kedokteran

Lina Nurbaiti

Universitas Mataram Fakultas Kedokteran

Nurhandini Eka Dewi

Dinas Kesehatan Provinsi Nusa Tenggara Barat

Rini Sekartini

Universitas Indonesia

Research article

Keywords: complementary feeding, stunting, knowledge, practices, attitude

Posted Date: July 21st, 2020

DOI: https://doi.org/10.21203/rs.3.rs-42167/v1

License: (c) (i) This work is licensed under a Creative Commons Attribution 4.0 International License. Read Full License 


\section{Abstract}

\section{Background}

Stunting is one of the major child public health concerns in Indonesia. West Nusa Tenggara (WNT) province, specifically, is still struggling to reduce its stunting prevalence as it is still higher than the average national prevalence, accounted for $31.4 \%$ in 2018 . Ensuring knowledge, attitude, and practices (KAP) of complementary feeding among parents is relevant to succeeding in the implementation of stunting reduction programs. This study aimed to assess the effectiveness of interventions in the form of seminar and workshop on preparing complementary feeding in stunting villages in Central Lombok, Indonesia.

Methods

This is a quasi-experimental community-based study, held in three stunting villages of Central Lombok, WNT, from June until August 2019. Three villages were chosen randomly from ten stunting-villages in Central Lombok District and divided into three groups, i.e., control group, seminar group and seminar and workshop group. We assessed KAP before and after intervention with a four-week interval.

Results

A total of 205 participants were enrolled in this study, consisting of 67,70 , and 68 participants for the control group, the first intervention group, and the second intervention group, respectively. Most participants had poor knowledge (75.1\%) of complementary feeding in the baseline assessment. We found an insignificant change in knowledge, but notable alterations in attitudes and practices after intervention. Seminar intervention could increase practice, while complete intervention (seminar and workshop) could increase both practices and attitudes significantly $(p=0.015$ dan $p=0.014)$. We found that complete intervention was more effective in increasing attitudes compared to the control group $(p=0.039)$. In contrast, practices in both seminar and complete intervention was increased effectively than controls $(p=$ 0.006 vs. $p=0.008)$, and no differences between seminar and complete intervention group $(p=0.943)$.

Conclusions

Complementary feeding KAP among parents in stunting villages in Central Lombok was inadequate. Our study showed that the combination of seminar and workshop increased parents' attitudes and practices, while the seminar only increased parents' practices. We suggest further prospective study to assess how long the effectivity of such interventions could impact and last; and obtain any cultural concerns.

Trial registration: 376/UN18.8/ETIK/2018

\section{Introduction}

Globally, stunting prevalence had been successfully reduced from $47 \%$ in 1980 to $33 \%$ in 2000 , yet this did not occur equally for all countries. ${ }^{1}$ In 2015, Indonesian government decided to prioritize stunting reduction program due to its high prevalence in $2013(37.2 \%) .{ }^{1-3}$ However, despite the government efforts and decreased of stunting national prevalence into $30.8 \%$ in 2018 , West Nusa Tenggara (WNT) province had their number higher than the average national prevalence, accounted for $31.4 \%$ in $2018 .{ }^{4}$

Considering the short term and long term consequences of stunting, Indonesia has been actively participating in stunting reduction programs - such as Scaling Up Nutrition (SUN) and Gerakan 1000 Hari Pertama Kehidupan (First 1000 days of Life Movement) - to accelerate the prevalence reduction. ${ }^{3,5}$ As one of the programs in both movements, improving complementary feeding practices are essential to serving as stunting-specific interventions. After the first six months of life, breast milk falls shorts on providing full nutritional requirements for infants; and complementary feeding plays a critical role in providing sufficient nutrition for growing infants.

The World Health Organization (WHO) (2001) describes the main principles of appropriate complementary feeding practices as timely (foods starts being introduced from 6 months), adequate (foods should provide sufficient energy, protein, and micronutrien for child's nutritional needs), safe (foods are hygienically stored, prepared, and fed), and properly fed (foods are given consistent with a child's signal of appetite and satiety, and that meal frequency and feeding method are suitable for age). ${ }^{6}$ However, complementary feeding in Indonesian children above six months of age was less than ideal, ${ }^{6}$ in terms of: introduction time, frequency, texture, feeding methods, sanitation and hygiene, dietary quality (lack of animal-based protein), and adequacy of essential vitamin, minerals, and calories. ${ }^{7,8,9}$

Although promoting appropriate complementary feeding practices has been addressed as an important strategy to combat stunting, the practical promotion program is still lack and scarce. Health promotion through community platform is an effective and potential way to 
reach all segments with nutrition interventions and health services. ${ }^{10}$ Despite its effectiveness in increasing positive attitudes and lift detrimental beliefs and perceptions, no seminar or workshop is available to improve mothers' knowledge. $^{11}$

Based on the facts as mentioned earlier, ensuring knowledge, attitude, and practices (KAP) of complementary feeding among parents in stunting villages in Central Lombok are relevant to succeeding the implementation of stunting reduction programs. As we argue that there is lack of practical education program for complementary feeding practices in Indonesia, we also aim to deliver interventions in form of seminar and workshop on preparing complementary feeding and compare the effectiveness of such programs by measuring mother's KAP after the intervention. As far as we know, there is no existing similar study in Indonesia that assess and deliver the same intervention as what we have planned. Therefore, this study would be a significant reference for future studies in order to support the reduction of stunting prevalence programs in Indonesia.

\section{Methods}

\section{Research Design}

This is a quasi-experimental community-based study, held in three stunting villages of Central Lombok, West Nusa Tenggara, from June until August 2019. Three villages were chosen randomly from ten stunting-villages in Central Lombok District, and divided into three groups:

A. No intervention : control group

B. One intervention : one-day seminar regarding stunting and complementary feeding

C. Two interventions: one-day seminar along with cooking session workshop regarding stunting and complementary feeding.

\section{Population and Subjects}

Population of this study consists of parents with children aged 6-12 months living in three stunting-villages enlisted by the Department of Health Central Lombok, West Nusa Tenggara. All parents from 6-12 months children in those selected villages were invited to participate and provided a plain language statement and an inform-consent form. Those who agreed to participate were prescreened and interviewed for their baseline data, and recruited.

\section{Inclusion Criteria}

1. Parents living and registered in 3 stunting villages, Central Lombok, West Nusa Tenggara. Parents could be represented as mother, father, or guardians who take care of the child.

2. Parents of children aged 6-12 months living in stunting villages.

3. Parents who agree to participate in the research by signing informed-consent.

\section{Exclusion Criteria}

1. Non-cooperative parents.

2. Parents who do not complete the questionnaire according to the given

\section{Sampling}

Sample of participants determined by this following formula:

$$
\mathrm{N}_{1}=\mathrm{N}_{2}=\frac{(Z \alpha+Z \beta)^{2} \pi}{\left(P_{1}-P_{2}\right)^{2}}
$$

in which $z$ is the score of normal deviate for two-tailed alternative hypothesis at level of significance 1.96 for Za and 0.84 , $\pi$ is the discordant proportion (0.3), and $\mathrm{P}_{1}-\mathrm{P}_{2}$ is the hypothetical percentage of two different groups (20\%). After adding loss to follow-up $10 \%$, eventually the minimum sample size is 66 for each group. 


\section{Research Procedures}

\section{Ethics statement}

The study protocol and all amendments were reviewed and approved by the Health Research Ethics Committee of the Faculty of Medicine, Mataram University, in compliance with local law. Prior to the study, informed consent was obtained from all subjects, i.e. parents or guardians of the children (6-12 months old).

\section{Subject allocation}

The allocation of intervention were performed randomly using SPSS software. Due to the nature of the study, all participants were aware of their allocation, however they did not know what were the intervention given to other villages.

\section{Research protocols and data collection}

The selection of study sites were assisted by the local authority, i.e. the Department of Health Central Lombok to ensure the selection of villages with high-stunting prevalence which have similar baseline characteristics. Furthermore, the selection of participants were conducted during the held of Integrated Service Post (Pos Pelayanan Terpadu/Posyandu) in each subvillages. Each villages usually have 15-20 subvillages, and there would be an Integrated Service Post performed for every month.

The eligibility assessment was conducted for every parents that came to the Integrated Service Post. Subsequently, every eligible participant would undergo several assessment including baseline survey, containing details of the parent-child information, and family characteristics; and anthropometric measurement for both children and parent. Interview was performed similarly among all participants by a trained research personnel using a validated questionnaire built specifically for this study. Anthropometric measurements were conducted with calibrated measuring instrument, using Omron weight scale and Omron length board for baby, and measurement tape designed by the Indonesian Ministry of Health to measure upper arm length circumference, and measurement tape for head circumference. The anthropometric measurement for parent was performed using digital scale for weight, and stature meter for height, and measurement tape designed by the Indonesian Ministry of Health to measure mid-upper arm circumference.

The first knowledge, attitudes, and practices (KAP) assessment was also performed in this session. The KAP questionnaire consisted of 10 items for knowledge, 6 items for attitude, and 7 items for practices, with 1, 3, and 5 score for a correct answer for knowledge, attitude, and practices respectively. After all eligible participants had been assessed and provided their inform-consent, research team scheduled the upcoming intervention sessions for the two intervention groups, and scheduled the appointment for the second KAP assessment for the control group. The second KAP assessment was conducted for all villages, with a 4 week interval from the first KAP assessment. (Figure 1)

As there were two intervention arms in this trial, we prepared two interventions consisting of seminar session for group 1 and seminar and workshop session for group 2. Interventions were delivered similarly to both arms by the same team consiting of general practitioners and a paediatrician. The detail for interventions are as followed: (Figure 1)

\section{Seminar session}

Seminar is aimed to increase knowledge, attitude, and practices theory on complementary feeding practices. We delivered two major lectures, i.e. stunting and complementary feeding practices. Materials include: complementary feeding principles, planning of complementary feeding, food safety and hygiene, complementary-feeding menu arrangement (focus on animal-source protein), food processing and handling, complementary feeding preparation and administration. All materials were excerpted from guidelines published by the Indonesian Ministry of Health, the Indonesian Paediatric Society (IPS), and WHO. Each participants also received a booklet of complementary feeding practice published by IPS and a stunting pamphlet published by the Indonesian Ministry of Health.

\section{Practical session}

Practical session is aimed specifically to make sure that parents can prepare and serve complementary feeding according to recommended practices. We divided participants into several small groups, provided complete sets of food and tools, and performed a cooking demonstration. Participants were also given hands-on time to try and practice: proper food handling; food safety and hygiene; types of food source, emphasizing on animal-protein source; right texture and amount of complementary feeding; and responsive feeding. (Additional File

2)

\section{Blinding}

No blinding was done in this study. 


\section{Statistical Analysis}

Collected data was analyzed with IBM SPSS Statistics version 22.0. Double entry was performed before the analysis, to avoid data entry errors. Primary outcomes include the knowledge, attitudes, and practices from participants, before and after intervention, i.e. in four-week interval. We classified the KAP score into three categories, i.e. poor (0-4), fair (5-7), and good (8-10) for knowledge; poor (3-8), fair (9-13), and good (14-18) for attitudes; and poor (7-17), fair (18-26), and good (27-35) for practices. The primary analysis was by intention to treat. The mean differences from pre and post-test are determined using Wilcoxon test, while the inter-group comparisons were calculated using ANOVA test. Analyses were done at a two-sided a level of 0.05 .

\section{Results}

\section{Socio-demographic characteristics}

A total of 205 participants were enrolled in this study, consisting of 67,70 , and 68 participants for control group, 1 st intervention group, and 2nd intervention group respectively. (Fig. 2) The mean of mother's age was similar across the groups, with the mean of age for all participants of 27.86 years old. Most of the participants in the three groups $(>60 \%)$ were categorized as having low education, i.e. total education time of less than 9 years. More than two-thirds of the participants $(78.0 \%)$ had income under provincial minimum wage in that area, that is less than IDR 1.850.000. Exclusive breastfeeding rate in our study (50.2\%) was found to be lower than national rate of $74.5 \%$. Furthermore, in our study setting, the introduction of complementary feeding was performed mostly at 6 months (77.1\%). (Table 1) 
Table 1

Socio-demographic characteristics

\begin{tabular}{|c|c|c|c|c|c|c|c|c|}
\hline \multirow[b]{2}{*}{ Variables } & \multicolumn{2}{|c|}{ Total } & \multicolumn{2}{|c|}{ Control } & \multicolumn{2}{|c|}{$\begin{array}{l}\text { Group } 1 \\
\text { (seminar) }\end{array}$} & \multicolumn{2}{|c|}{$\begin{array}{l}\text { Group } 2 \\
\text { (seminar + WS) }\end{array}$} \\
\hline & $\mathbf{n}$ & $\%$ & $\mathbf{n}$ & $\%$ & $\mathbf{n}$ & $\%$ & $\mathbf{n}$ & $\%$ \\
\hline Overall & 205 & - & 67 & 32.7 & 70 & 34.1 & 68 & 33.2 \\
\hline $\begin{array}{l}\text { Mother's age } \\
\text { (mean } \pm S D)\end{array}$ & \multicolumn{2}{|c|}{$27.86 \pm 7.01$} & \multicolumn{2}{|c|}{$28.12 \pm 6.71$} & \multicolumn{2}{|c|}{$27.46 \pm 6.55$} & \multicolumn{2}{|c|}{$28.03 \pm 7.81$} \\
\hline $17-25$ & 84 & 41.0 & 28 & 41.8 & 30 & 42.9 & 26 & 38.2 \\
\hline $26-30$ & 56 & 27.3 & 17 & 25.4 & 23 & 32.9 & 16 & 23.5 \\
\hline $31-35$ & 28 & 13.7 & 12 & 17.9 & 5 & 7.1 & 11 & 16.2 \\
\hline $36-40$ & 26 & 12.7 & 7 & 10.4 & 9 & 12.9 & 10 & 14.7 \\
\hline $41-45$ & 10 & 4.9 & 3 & 4.5 & 3 & 4.3 & 4 & 5.9 \\
\hline \multicolumn{9}{|l|}{ Mother's education } \\
\hline Low (9 years/less) & 131 & 63.9 & 43 & 64.2 & 46 & 65.7 & 42 & 61.8 \\
\hline Middle (High sc) & 54 & 26.3 & 17 & 25.4 & 22 & 25.4 & 15 & 22.1 \\
\hline High (Dipl/Bach) & 20 & 9.8 & 7 & 10.4 & 2 & 10.4 & 11 & 16.2 \\
\hline \multicolumn{9}{|l|}{ Household's income } \\
\hline Low & 160 & 78.0 & 60 & 89.5 & 50 & 71.4 & 50 & 73.5 \\
\hline Middle low & 29 & 14.1 & 5 & 7.5 & 12 & 17.1 & 12 & 17.6 \\
\hline Middle high & 16 & 7.8 & 2 & 3.0 & 8 & 11.4 & 6 & 8.8 \\
\hline Child's age (mean \pm SD) & \multicolumn{2}{|c|}{$9.77 \pm 1.99$} & \multicolumn{2}{|c|}{$10.48 \pm 2.08$} & \multicolumn{2}{|c|}{$9.34 \pm 1.82$} & \multicolumn{2}{|c|}{$9.52 \pm 1.89$} \\
\hline \multicolumn{9}{|l|}{ Sex } \\
\hline Male & 89 & 43.4 & 30 & 44.8 & 26 & 37.1 & 33 & 48.5 \\
\hline Female & 116 & 56.6 & 37 & 55.2 & 44 & 62.9 & 35 & 51.5 \\
\hline \multicolumn{9}{|l|}{ Breastfeeding } \\
\hline Exclusive & 103 & 50.2 & 30 & 44.8 & 37 & 52.9 & 36 & 52.9 \\
\hline Partial & 99 & 48.3 & 36 & 53.7 & 32 & 45.7 & 31 & 45.6 \\
\hline Not at all & 3 & 1.5 & 1 & 1.5 & 1 & 1.4 & 1 & 1.4 \\
\hline \multicolumn{9}{|l|}{ Immunization status } \\
\hline Complete & 157 & 76.6 & 53 & 79.1 & 46 & 65.7 & 58 & 85.3 \\
\hline Incomplete & 48 & 23.4 & 14 & 20.9 & 24 & 34.3 & 10 & 14.7 \\
\hline \multicolumn{9}{|c|}{ First complementary feeding } \\
\hline$<6$ month & 16 & 7.8 & 8 & 11.9 & 5 & 7.1 & 3 & 4.4 \\
\hline 6 month & 158 & 77.1 & 45 & 67.2 & 56 & 80.0 & 57 & 83.8 \\
\hline$>6$ month & 31 & 15.1 & 14 & 20.9 & 9 & 12.9 & 8 & 11.8 \\
\hline
\end{tabular}


Most of participants (>60\%) in the three study sites have given complementary feeding in the right time (6 months), in which the control group has the lowest proportion compared to other sites. The food texture given to the children according to children's age are still in low proportion, and still not following any existing guidlines. In the aspects of hygiene and the adminsitration of food, most of participants are in accordance with guideline and have a high proportion. (Table 2)

Tabel 2. Complementary feeding profile

\begin{tabular}{|c|c|c|c|c|}
\hline \multicolumn{2}{|c|}{ Parameters } & \multicolumn{3}{|c|}{ Proportions (\%) } \\
\hline & & Control & Group 1 & Group 2 \\
\hline \multirow[t]{3}{*}{ Time of administering complementary feeding } & $<6$ months & 11 & 7.1 & 4.4 \\
\hline & 6 months & 67 & 80 & 83.8 \\
\hline & $>6$ months & 20.9 & 12.9 & 11.8 \\
\hline \multirow[t]{8}{*}{ Food texture } & 6-9 months & 19.4 & 32.9 & 12 \\
\hline & Crushed & 40.3 & 47.1 & 52.2 \\
\hline & Mushy & 14.9 & 17.1 & 26.9 \\
\hline & Adults texture & 25.3 & 2.9 & 9 \\
\hline & 9-12 months & 0 & 3.1 & 0 \\
\hline & Crushed & 10.9 & 15.6 & 25.7 \\
\hline & Mushy & 26.1 & 25 & 34.3 \\
\hline & Adults texture & 63 & 56.3 & 40 \\
\hline \multirow[t]{4}{*}{ Hygiene } & Always wash hands but without soap & 26.9 & 21.4 & 13.2 \\
\hline & Always wash hands with soap & 26.9 & 21.4 & 13.2 \\
\hline & Always wash raw foods & 79.1 & 84.2 & 95.5 \\
\hline & Always boil water & 82.1 & 97.1 & 92.6 \\
\hline \multirow[t]{2}{*}{ Food administration } & Feeding while playing & 98.5 & 97.1 & 100 \\
\hline & Feeding with forced & 0 & 1.4 & 0 \\
\hline
\end{tabular}

Results from baseline and follow-up knowledge, attitudes, and practices (KAP) are presented in Table 3. The majority of participants had poor knowledge $(75.1 \%)$ of complementary feeding. Each answer of the questions given regarding knowledge, attitudes, and practices are shown in Table 4. It could be observed that in general, the KAP results in the follow-up assessment showed an insignificant change in knowledge, but notable alterations in attitudes and practices aspects (Table 5).

'able 3. Respondents' baseline and follow-up knowledge, attitude, and practice

of complementary feeding 


\begin{tabular}{|c|c|c|c|c|c|c|c|c|}
\hline \multirow{4}{*}{ Variables } & \multirow{2}{*}{\multicolumn{2}{|c|}{$\begin{array}{l}\text { Total } \\
\text { n (\%) }\end{array}$}} & \multirow{2}{*}{\multicolumn{2}{|c|}{ Control }} & \multirow{2}{*}{\multicolumn{2}{|c|}{$\begin{array}{l}\text { Group } 1 \\
\text { (seminar) }\end{array}$}} & \multicolumn{2}{|c|}{ Group 2} \\
\hline & & & & & & & (seminar & + WS) \\
\hline & \multicolumn{2}{|c|}{$205(100 \%)$} & \multicolumn{2}{|c|}{$67(32.7 \%)$} & \multicolumn{2}{|c|}{$70(34.1 \%)$} & \multicolumn{2}{|c|}{$68(33.2 \%)$} \\
\hline & Baseline & FU & Baseline & FU & Baseline & FU & Baseline & FU \\
\hline \multicolumn{9}{|l|}{ Knowledge } \\
\hline \multirow[t]{2}{*}{ Poor (0-4) } & 154 & 150 & 44 & 49 & 56 & 56 & 54 & 45 \\
\hline & $(75.1)$ & $(73.2)$ & $(65.7)$ & (73.1) & $(80.0)$ & $(80.0)$ & $(79.4)$ & (66.2) \\
\hline \multirow[t]{2}{*}{ Fair (5-7) } & 43 & 52 & 23 & 18 & 10 & 13 & 10 & 21 \\
\hline & $(21.0)$ & $(25.4)$ & (34.3) & (26.9) & (14.3) & (18.6) & $(14.7)$ & (30.9) \\
\hline \multirow[t]{2}{*}{ Good (8-10) } & 8 & 3 & 0 & 0 & 4 & 1 & 4 & 2 \\
\hline & (3.9) & (1.5) & $(0)$ & $(0)$ & (5.7) & (1.4) & (5.9) & (2.9) \\
\hline \multicolumn{9}{|l|}{ Attitude } \\
\hline \multirow[t]{2}{*}{ Poor (3-8) } & 29 & 22 & 15 & 12 & 4 & 6 & 10 & 4 \\
\hline & $(14.1)$ & $(10.7)$ & $(22.4)$ & (17.9) & (5.7) & (8.6) & (14.7) & (5.9) \\
\hline \multirow[t]{2}{*}{ Fair (9-13) } & 128 & 119 & 43 & 40 & 42 & 41 & 43 & 38 \\
\hline & $(62.4)$ & (58) & $(64.2)$ & (59.7) & $(60.0)$ & (58.6) & $(63.2)$ & (55.9) \\
\hline \multirow[t]{2}{*}{ Good (14-18) } & 48 & 64 & 9 & 15 & 24 & 23 & 15 & 26 \\
\hline & $(23.4)$ & $(31.2)$ & $(13.4)$ & $(22.4)$ & (34.3) & (32.9) & $(22.1)$ & (38.2) \\
\hline \multicolumn{9}{|l|}{ Practice } \\
\hline \multirow[t]{2}{*}{ Poor (7-17) } & 1 & 1 & 1 & 1 & 0 & 0 & 0 & 0 \\
\hline & $(0.5)$ & $(0.5)$ & (1.5) & (1.5) & (0) & $(0)$ & (0) & $(0)$ \\
\hline \multirow[t]{2}{*}{ Fair (18-26) } & 106 & 76 & 39 & 33 & 34 & 22 & 33 & 21 \\
\hline & (51.7) & (37.1) & $(58.2)$ & $(49.3)$ & $(48.6)$ & (31.4) & $(48.5)$ & (30.9) \\
\hline \multirow[t]{2}{*}{ Good (27-35) } & 98 & 128 & 27 & 33 & 36 & 48 & 35 & 47 \\
\hline & (47.8) & (62.4) & (40.3) & (49.3) & (51.4) & (68.6) & (51.5) & (69.1) \\
\hline
\end{tabular}

$F U=$ Follow-up 
Table 4

Respondents' knowledge, attitude, and practice of complementary feeding

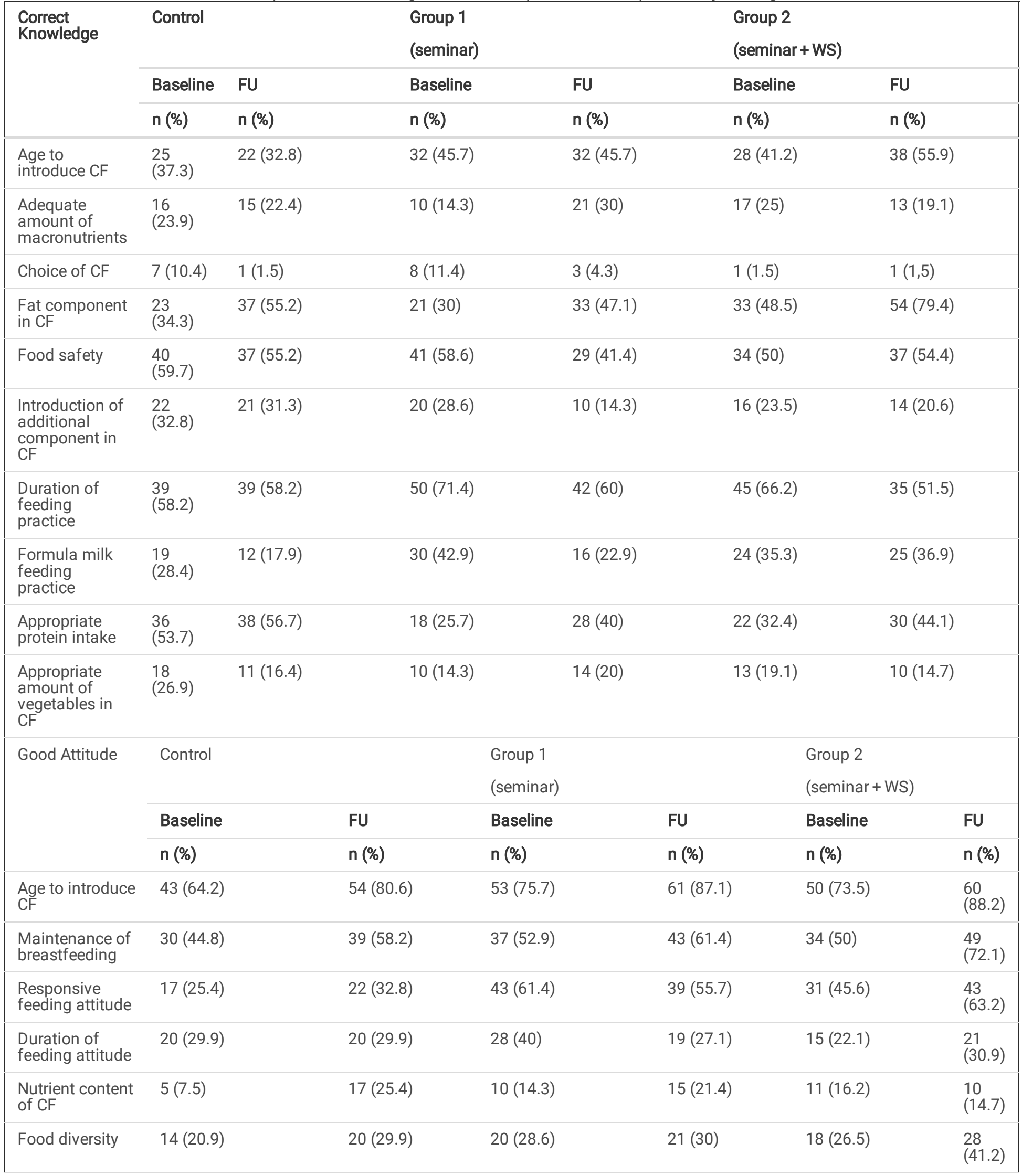

$\mathrm{FU}=$ Follow-up 


\begin{tabular}{|c|c|c|c|c|c|c|c|}
\hline \multirow[t]{3}{*}{$\begin{array}{l}\text { Correct } \\
\text { Knowledge }\end{array}$} & \multicolumn{3}{|l|}{ Control } & \multicolumn{2}{|l|}{$\begin{array}{l}\text { Group } 1 \\
\text { (seminar) }\end{array}$} & \multicolumn{2}{|l|}{$\begin{array}{l}\text { Group } 2 \\
\text { (seminar + WS) }\end{array}$} \\
\hline & Baseline & \multicolumn{2}{|l|}{ FU } & Baseline & FU & Baseline & FU \\
\hline & n (\%) & \multicolumn{2}{|l|}{$\mathrm{n}(\%)$} & n (\%) & $n(\%)$ & $n(\%)$ & $\mathrm{n}(\%)$ \\
\hline \multirow[t]{4}{*}{ Good Practice } & Control & & & Group 1 & & Group 2 & \\
\hline & & & & \multicolumn{2}{|l|}{ (seminar) } & \multicolumn{2}{|c|}{ (seminar + WS) } \\
\hline & Baseline & & FU & Baseline & FU & Baseline & FU \\
\hline & $\mathrm{n}(\%)$ & & n (\%) & $\mathrm{n}(\%)$ & n (\%) & n (\%) & n (\%) \\
\hline Meal frequency & $37(55.2)$ & & $23(34.3)$ & $34(48.6)$ & $32(45.7)$ & $31(45.6)$ & $31(45.6)$ \\
\hline $\begin{array}{l}\text { Continued } \\
\text { breastfeeding }\end{array}$ & $53(79.1)$ & & $43(64.2)$ & $55(78.6)$ & $44(62.9)$ & $59(86.9)$ & $44(64.7)$ \\
\hline $\begin{array}{l}\text { Responsive } \\
\text { feeding } \\
\text { practice }\end{array}$ & $20(29.9)$ & & $25(37.3)$ & $36(51.4)$ & $33(47.1)$ & $20(29.4)$ & $33(48.5)$ \\
\hline $\begin{array}{l}\text { Hygiene } \\
\text { practice }\end{array}$ & $34(50.7)$ & & $35(52.2)$ & $42(60)$ & $37(52.9)$ & $31(45.6)$ & $45(66.2)$ \\
\hline $\begin{array}{l}\text { Food } \\
\text { preparation } \\
\text { safety }\end{array}$ & $34(50.7)$ & & 39 (58.2) & $46(65.7)$ & $49(70)$ & $46(67.6)$ & $53(77.9)$ \\
\hline $\begin{array}{l}\text { Appropriate } \\
\text { duration of } \\
\text { feeding }\end{array}$ & $7(10.4)$ & & $11(16.4)$ & $7(10)$ & $9(12.9)$ & $10(14.7)$ & $6(8.8)$ \\
\hline $\begin{array}{l}\text { Adequate } \\
\text { macronutrient } \\
\text { intake }\end{array}$ & $8(11.9)$ & & $4(6)$ & $6(8.6)$ & $9(12.9)$ & $4(5.9)$ & $5(7.5)$ \\
\hline \multicolumn{8}{|l|}{ FU = Follow-up } \\
\hline $\mathrm{CF}=$ complementary & eeding & & & & & & \\
\hline
\end{tabular}


Table 5

Mean difference between baseline and follow-up

\begin{tabular}{|c|c|c|c|c|c|c|c|c|}
\hline \multirow[b]{2}{*}{ Overall } & \multicolumn{2}{|l|}{ Total } & \multicolumn{2}{|c|}{ Control } & \multicolumn{2}{|c|}{$\begin{array}{l}\text { Group } 1 \\
\text { (seminar) }\end{array}$} & \multicolumn{2}{|c|}{$\begin{array}{l}\text { Group } 2 \\
\text { (seminar + WS) }\end{array}$} \\
\hline & 205 & 100 & 67 & 32.7 & 70 & 34.1 & 68 & 33.2 \\
\hline Variables & $\mathbf{n}$ & $(\%)$ & $\mathbf{n}$ & $(\%)$ & $\mathbf{n}$ & $(\%)$ & $\mathbf{n}$ & $(\%)$ \\
\hline $\begin{array}{l}\text { Knowledge Differ } \\
\text { P-value }(95 \% \mathrm{Cl})\end{array}$ & ences & & \multicolumn{2}{|c|}{$0.409(-0.61 ; 0.25)$} & 0.47 & $(-0.65 ; 0.31)$ & \multicolumn{2}{|c|}{$0.151(-0.13 ; 0.84)$} \\
\hline Decrease & 80 & (39) & 29 & (43.3) & 26 & (37.1) & 25 & $(36.8)$ \\
\hline Stable/Increase & 125 & (61) & 38 & $(56.7)$ & 44 & $(62.9)$ & 43 & (63.2) \\
\hline $\begin{array}{l}\text { Attitude Differenc } \\
\text { P-value }(95 \% \mathrm{Cl})\end{array}$ & & & 0.01 & $(0.21 ; 1.67)$ & 0.52 & $(-0.94 ; 0.49)$ & 0.00 & $0.39 ; 1.79)$ \\
\hline Decrease & 72 & $(35.1)$ & 22 & (32.8) & 28 & $(40)$ & 22 & (32.4) \\
\hline Stable/Increase & 133 & $(64.9)$ & 45 & $(67.2)$ & 42 & $(60)$ & 46 & $(67.6)$ \\
\hline $\begin{array}{l}\text { Practice Differenc } \\
\text { P-value }(95 \% \mathrm{Cl})\end{array}$ & & & 0.17 & $(-0.32 ; 1.76)$ & 0.04 & $(0.04 ; 1.99)$ & 0.00 & $0.37 ; 2.13)$ \\
\hline Decrease & 75 & $(36.6)$ & 30 & $(44.8)$ & 26 & $(37.1)$ & 19 & $(27.9)$ \\
\hline Stable/Increase & 130 & $(63.4)$ & 37 & $(55.2)$ & 44 & $(62.9)$ & 49 & $(72.1)$ \\
\hline
\end{tabular}

\section{Effectivity of intervention within each group}

The mean differences in KAP between baseline and follow-up assessments were analyzed using t-test analysis (Table 5). Wilcoxon analysis of baseline and follow-up knowledge showed slight increase after intervention compared to control group, but not statistically significant. Seminar intervention could increase practice, while complete intervention (seminar and workshop) could increase both practice and attitude significantly. (Fig. 3)

\section{Effectivity of intervention between groups}

Figure 4 shows no significant difference between control and intervention groups. Complete intervention was shown to be more significant than control or seminar intervention group in increasing respondents' attitude. Complete intervention group and seminar group were more effective significantly in increasing respondents' practice compared to control group.

\section{Factors associated with respondents' baseline complementary feeding knowledge, attitude, and practice}

Fisher exact test showed no significant association between mothers' complementary feeding knowledge, attitude, and practice with mother's age, education, and income (Additional File 1).

\section{Correlations between knowledge, attitude, and practice}

Using Spearman correlation test, it is found that attitude correlated with knowledge $(\mathrm{P}=0.004 ; 99 \% \mathrm{Cl})$ and practice $(\mathrm{P}=0.002 ; 99 \% \mathrm{Cl})$ significantly, while knowledge is not correlated with practice $(P=0.949)$.

\section{Discussion}

Studies on Knowledge, Attitude, and Practice of Complementary Feeding

Complementary feeding is starting when breast milk alone is no longer sufficient to meet the nutritional requirements of infant, therefore other foods are needed while continuing to breastfed ${ }^{12}$. Knowledge, attitude, and practice of parents towards complementary feeding is important role to make successfull complementary feeding process. WHO recommends to introduce complementary feeding at 6 months. 
Knowledge of timing to start complementary feeding was varied among some studies. In our study, parent's knowledge of timely complementary feeding before intervention was $37.3 \%$ in control, $45.7 \%$ in group 1 , and $41.2 \%$ in group 2 . This number was found lower compared to other studies, such as in Pakistan (54\%), Karachi (57.2\%), and Ghana (60\%). ${ }^{13}$ Another study in South Ethopia showed that $72.5 \%$ mothers of children aged 6-23 months knew the initiation time of complementary feeding, which is less when compared to study in South India in 2011 (77.5\%). ${ }^{13,14}$ Aggarwal et al observed that only 17.5\% mothers had started complementary feeding at recommnended time and in a study held in slums of Delhi observed $16.6 \%$ of parents had initiated feed at the right time. Those studies showed lower level of mothers knowledge of initiation complementary feeding time than our study. After intervention, our study showed that the knowledge of timing to start complementary feeding was increased from $41.2-55.9 \%$ in group 2 (seminar and workshop intervention). In a contrary, our study found that the mean of parent's attitude of timely complementary feeding was good with $64.2 \%$ in control group, $75.7 \%$ in group 1 , $73.5 \%$ in group 2 before intervention and $80.6 \%$ in control group, $87.1 \%$ in group 1, and $88.2 \%$ in group 2 after intervention.

The recommended feeding frequency form WHO is two to three times at 6-8 months and three to four times at 9-12 months, with once to twice additional meal per day. Study in Nigeria showed only half of the responden knew the correct frequency, however another study in Ghana showed that almost all of the responden knew the correct frequency. In a similar study in Allahabad, only $38.7 \%$ of children received proper complementary feeding. ${ }^{14}$ Our study found that $55.2 \%$ in control, $48.6 \%$ in group 1 , and $45.6 \%$ in group 2 parents have been given the correct meal frequency before intervention and $34.4 \%$ in control, $45.7 \%$ in group 1, and $45.6 \%$ in group 2 after intervention. This finding was similar with the study finding in slums areas of Bahir Dar City, Ethiopia (47\%), ${ }^{15}$ India (48.6\%) ${ }^{16}$ and Pakistan (62\%) ${ }^{17}$

Besides minimum meal frequency, the adequacy of miconutrients and macronutrients are important. Complentary food should be varied and include adequate macronutrients and macronutrients. Micronutrient needs are high during the first 2 years of life due to rapid rate of growth and development. ${ }^{6,18}$ In our study, parent's knowledge, attitude, and practice of adequate macronutrients and micronutirents in complementary food was poor before intervention. After intervention, parent's attitude of adequate amount of macronutrient was raised into $25.4 \%$ in control, $21.4 \%$ in group 1 , and $14.7 \%$ in group 2 . However, this attitude was still in low level. Other study held in 2018 showed that $27.3 \%$ mothers were aware that adding oil enriches children's porridge nutritionally and $31.8 \%$ of mothers knew that childrean's meal should be balanced. ${ }^{19}$ Another study in Sri Lanka showed that oil had been introduced to $84.9 \%$ of infants by the end of 12 months. ${ }^{20}$ In our study, only $34.3 \%$ parents in control group, $30 \%$ in group 1 , and $48.5 \%$ in group 2 had the correct knowledge of fat component in complementary feeding before intervention but increased by $55.2 \%$ in control group, $47.1 \%$ in group 1, and $79.4 \%$ in group 2 after intervention. A study conducted in Urganda reported that majority of children were given cereals in the last 24 hours. Only $0.5 \%$ mother gave meat and milk products. Cereal based foods alone are not sufficient. ${ }^{21}$ WHO recommended mother to feed their children with locally available foods which contain calories, proteins, mineral, and vitamins. Our study reported parent's knowledge of source of protein was low to moderate before intervention (53.7\% in control group, $25.7 \%$ in group 1, 32.4\% in group 2). A increase knowledge of source of protein intake was noted after intervention $(56.7 \%, 40 \%$, and $44.1 \%$ in control, group 1, and group 2 respectively). The use of fortified complementary food may be necessary to ensure adequacy of nutrient intakes. ${ }^{12}$ Hasnain et al $^{17}$ reported that $82 \%$ respondents of their study knew that homemade food is good, but only $42 \%$ were giving them home made food. Our study found that only $10.4 \%$ in control group, $11.4 \%$ in group 1 , and $1.5 \%$ in group 2 knew that fortified food can be used as complementary food.

Food diversity recognized as a key of high quality diets. WHO guideline recommend that child should eat meatt, poultry, fish, or eggs as often as possible. Vitamin A rich fruits andvegetables also should be eaten daily. In our study, food diversity among parents attitude was low ( $20.9 \%$ in control group, $28.6 \%$ in group 1 , and $26.5 \%$ in group 2 ) before intervention. The percentage increased after intervention but still in low level (29.9\% in control gorup, 30\% in group 1, and $41.2 \%$ in group 2 ). Another study showed that majority of the children had eaten food from grain, tubers, roots like porridge, rice, bread, and cassavas. The study also found that consumption of iron rich foods was low, because animal protein are most likely out of financial reach for the majority participants. According to study in Sri Lanka, animal product protein intake was very low, fish and eggs were consumed by $25 \%$ and $18 \%$ of infants. However, the other study in one area in Sri Lanka, Galle reported that inroduction rates of fish and eggs were high, $75 \%$ and $63 \%$. Consumption rates of pro vitamin A rich food (carrot and pumpkin) were also high (97\% and $90 \%){ }^{20}$ Senarath et $\mathrm{al}^{22}$ reported the variation of food was increased as the age of the child increased (40.1\% in $6-$ 8 month age group and $82.5 \%$ in $18-23$ month age group).

Safe preparation and storage of complementary feeding are also play important role. Washing parents' and children's hands before eating is recommended by WHO. In our study, practices of hand washing with water and soap was moderate before intervention (50.7\%, $60 \%$, and $45.6 \%$ in control, group 1, and group 2 respectively). A increase in parent's attitude was notable in control and group 2 after intervention. Mihreite ${ }^{23}$ also found the same result that majority of mothers in their study had high knowledge on hand hygiene practices; washing hands before preparing food (44.5\%) and treating of water used for preparing food for a child (46.4\%). Madhu et al ${ }^{21}$ reported from 200 partisipants in their study, $96 \%$ clean hands and utensils before feeding, $66 \%$ wash hands of children before feeding, and $61 \%$ boiling of drinking water.

Page $12 / 20$ 
Responsive feeding is one of complementary feeding practice principle recommended by WHO, including sensitive to children hunger and satiety cues, feed slowly and patiently, experiment with different food combination, taste, texture, minimize distractions during meal time, and talk to children during feeding. Inappropriate feeding practices are an important role of stunting. Parents are unaware of the importance of responsive feeding. ${ }^{24}$ Less than half of mothers reported the need for responsive feeding of complementary food to ensure optimal intakes (45.5\%). ${ }^{19}$ In our study, parent's knowledge of recommended feeding duration was poor, $58.2 \%$ in control group, $71.4 \%$ in group 1 , and $66.2 \%$ in group 2 didn't know the recommended feeding duration. The percentage was decreased after intervention, which is the knoweldge of recommended feeding duration was increased. This findings were followed by poor responsive feeding practice in all groups, only $29.9 \%$ in control group, $51.4 \%$ in group 1 , and $29.4 \%$ in group 2 practiced responsive feeding before intervention.

Continuing breastfeeding until two years of age or beyond make an important contribution to maximize child's growth, because of its energy and essential fatty acids content. Breast milk also provides substantial amount of micronutrient. ${ }^{24}$ In this study, parent's attitude of continuing breastfeeding before intervention were $44.8 \%$ in control group, $52.9 \%$ in group 1, and $50 \%$ in group 2 respectively. Parent's attitude was increased in all group to $58.2 \%$ in control group, $61.4 \%$ in group 1 , and $72.1 \%$ in group 2 . This finding in lower that other study in Ethiopia, about $92 \%$ and $94 \%$ of mothers have continued to breastfeed their children at age one and two respectively. ${ }^{15}$ The majority of women participated in that study were housewives which increases the likelihood of continuing to breastfeed. ${ }^{15}$ Meanwhile, our study found that parents had continued breastfed in 79.1\% (control), 78.6\% (group 1), and 86.9\% (group 2) before intervention.

Factors Affecting Complementary Feeding Knowledge, Attitude, and Practice

Our study found no correlation between mother's age, mother's education, and household income with parent's knowledge, attitude, and practice of complementary feeding $(p>0.05)$ (Additional File 1$)$. Nonetheless, some similar studies reported different findings with our study.

Education is one of important determinants of children's growth and development, such as association between parents' education level and appropriate infant feeding. Mother's education plays a significant role on proper infant feeding after a comparative study involving five Asian countries. ${ }^{22}$ However, Seram et al ${ }^{25}$ found no correlation between parents education and knowledge on complementary feeding. The result was in line with other study in rural Bangladesh that maternal education was not associated with timing of introduction of complementary food based on study in rural Bangladesh. Maternal knowledge or education may not be the foremost driever of child complementary feeding practice. ${ }^{19}$ Seranath et al ${ }^{22}$ in their study observed a linear correlation between meal frequency and maternal education, but it was not associated with others complementary feeding indicator i.e timely introduction of complementary feeding, food diversity, and minimal acceptable diet. Compared with mothers with higher levels of education, those who had completed secondary education or had not attended any level of education reported a higher risk for low diversity (OR 1.97 and 1.48). ${ }^{22}$ This result is in acordance to study in Kenya which found that level of education and knowledge of forbidden foods had a positive correlation. ${ }^{26}$

Economic status play role in fulfilling household resource including component of complementary food. Poverty was one of factor for inappropriate complementary feeding practice. Study in Wollow found that rich households had improved complementary feeding practice due to dietary diversity. ${ }^{27}$ Several studies also reported that the low income was a major constraining factor to food security. It may have contributed to inability to achieve minimum meal frequency and meal diversity. ${ }^{27,28}$ The study showed that diets of infant and young children in low income countries are iron, zinc, and B6 deficiency. ${ }^{24}$ This finding was confirmed by other study in Sri Lanka, the result showed that dietary diversity gradually declined with lower income. ${ }^{22}$

Study in Wanogo District, South Ethiopia in 2017 showed that culture plays a major role in feeding practices. Feeding culture in community is not in favor of recommended feeding guideline and was responsible for increasing the odds of inappropriate complementary feeding practice by $2.4 \%$. Most of participant in that study revealed that elders especially husbands was priority during feeding practice and the leftover was served for the child. ${ }^{27}$ Another study held in China found that mother introduced complementary food before six months, most offent at three months. They believed that there were some benefits to introduce Chinese traditional food earlier, included strengthening bone development, children learning to swallow food, prolonged satiety, accelerated growth, and improved digestive system. ${ }^{26}$ Similar to that studies, study in Lubao, Kenya reported that most of parents gave porridge to their child as early as the first month because they explained that porridge was good to make their child strong. The result of this study reported that culture was the reason of $54 \%$ parents to forbid their child to consume some foods. This study also reported that various diet restrictions and food taboos affected to infant feeding. A common taboo in the area were not fed children with eggs as they believe that eggs made speech delay. Some parts of meats especially organ meats also could not be eaten by children or women because it just served to men and some local belief to feed their children a small amount of ashes along with burning fish to help soothe the baby to sleep. ${ }^{26}$

Impact of Educational Interventions for Improving Parent's KAP on complementary feeding

Page $13 / 20$ 
Although having a similar general aim compared to other researches, our study strived to show a different parameter on the effectiveness of educational interventions in form of seminar and workshop by measuring the immediate change of parent's KAP in four weeks interval. It could be observed that the implementation of seminar have promoted a positive result in parent's practice, although it might not be in significant improvement. Furthermore, better improvements are also shown by the implementation of seminar and workshop, in which it encourages increased scores in parent's attitudes and practices.

The inadequate improvement in parent's knowledge observed in both first and second intervention groups raise an inquiry on the reason that might explain this drawback. It might be argued that this could be due to parent's education level that mostly $(>60 \%)$ are at low level (less than 9 years education time) and the short interval to the second assessment. Improvements found in the first and second intervention groups might be appeared as the results of direct replication from the given intervention. Furthermore, a study by Shi et al. in China which gathered their second follow-up data at 6 months successfully showed that the intervention group had a significant improvement in parent's complementary feeding practices. ${ }^{29}$ However, in this study, the intervention was slightly different with ours in which home visits were performed as an additional approach to the combination of group training, demonstration, and booklet administration.

In the implementation of the intervention, the involvement of the local health workers along with the community cadres and leaders are important to assure a successful intervention for the community. We managed to collaborate with the local primary health cares in the villages. However, several aspects could still be improved, such as implementing additional interpersonal session with the participants by having an individual counseling and home visit. This method was implemented by Hotz and Gibson in Malawi and resulted in improved knowledge ad behavior on food seection and preparation of parents. ${ }^{30}$ Other study by Shi et al also noted that the involvement of family members mainly husband and parents-in-law are also essential to create a supportive environment for the improvement of parents in complementary feeding. ${ }^{29}$ This study showed a significant result in parent's practice and also in children's anthropometry such as in increased weight gain and length.

Limitation

As blinding was not performed in this study, this research is prone to selection bias performed by trainers in the interventions. We have attempted to minimise the bias by having a training for all the trainers prior to the interventions in order to give a standardised and similar intervention for both the intervention groups. We were also unable to perform an individual consultation, assess any cultural concerns, and home-visit with the participants, and this might play a role on consolidating participant's knowledge on the new given information.

Furthermore, we only included one parent for every children, thus other family members that might have influence on the parents such as husband and mother-in-law were not enclosed in the intervention. We also noted that a longer interval follow-up, such as three and six months, should be incorporated in the study design to capture the longer change in parent's KAP.

\section{Conclusion}

Complementary feeding knowledge, attitude, and practice among parents in stunting village in Central Lombok were inadequate. Our study showed that the combination between seminar and workshop significantly increased parents attitude and practice, while seminar only increased parents practice. Differences between control group and complete intervention group (seminar and workshop) also statistically more significant in increasing parents attitude and practice. Improving complementary feeding knowledge, attitude, and practice requires multi dimensional approaches. We suggest further study to obtain cultural information and address, if any, all the cultural concerns regarding complementary feeding. We also recommend future prospective study to assess how long the effectivity of such interventions could impact and last.

\section{Abbreviations}

ANOVA

Analysis of Variance

$\mathrm{Cl}$

Confidence Interval

FU

Follow-Up

IBM

International Business Machines Corporation

IPS

Indonesian Pediatric Society

Page $14 / 20$ 
OR

Odds Ratio

SPSS

Statistical Package for the Social Sciences

SUN

Scalling Up Nutrition

WHO

World Health Organization

WNT

West Nusa Tenggara

\section{Declarations}

\section{Ethics approval}

Ethical permission for conducting study was granted by Ethical Committee for Medical Research, Faculty of Medicine, the University of Mataram, Indonesia. Register No: 376/UN18.8/ETIK/2018.

\section{Availability of data and materials}

The datasets used and/or analysed during the current study are available from the corresponding author on reasonable request.

\section{Consent for publication}

Not applicable.

\section{Competing interests}

The authors declare that they have no competing interests.

\section{Authors' contributions}

ZI drafted the manuscript. JT, AAS, TPK, and NEK designed the study. ZI, JT, and AAS wrote the grant application. LN helped assessment quality control, contacted local health department and primary health cares for permission, and gave seminar in local language. All authors are actively involved in the study and approved the final draft of the manuscript.

\section{Funding}

This study is funded by a grant from PT. Novell Pharmaceuticals Laboratories Indonesia, in collaboration with Indonesian Pediatrics Society, and Indonesia Endowment Fund for Education (Lembaga Pengelola Dana Pendidikan/LPDP) without any conflict of interest or intervention, either from PT. Novell Pharmaceuticals Laboratories Indonesia, Indonesian Pediatric Society, or Indonesia Endowment Fund for Education . Award Number: 1055 /PP IDAI/XI/2018. The authors declare that they have no financial relationships relevant to this article to disclose.

\section{Acknowledgement}

JT holds scholarship from Indonesia Endowment Fund for Education (LPDP), Ministry of Finance, Indonesia. We would like to thank Ristania Ellya John, Qisthinadia Hazhiyah Setiadi, Ni Komang Ayu Swanitri Wangiyana, Ratu Missa Qurani for helping data collection and input; Baiq Cantik Aprilla Ariyanti, Subula Robbiki Zulula, Intan Karmila, Salsabila Fitratunnisa, M. Junia Fahroni, Aurellia Clarissa Salsabila for helping data collection; Mantang Primary Health Care (Puskesmas), Teratak Primary Health Care, Teruwai Primary Health Care, and Central Lombok Health Department for being supportive and cooperative throughout the study.

\section{References}

1. de Onis M, Blössner M, Borghi E. Prevalence and trends of stunting among pre-school children, 1990-2020. Public Health Nutr. 2012;15(01):142-8. 
2. Ministry of Health and National Institute of Health Research and Development. National report on basic health research, Riskesdas, 2018. Jakarta, Indonesia, 2018.

3. Kementerian Kesehatan RI. Rencana Strategis Kementerian Kesehatan Tahun 2015-2019, Keputusan Menteri Kesehatan RI nomor HK.02.02/Menkes/52/2015. Jakarta: Kementerian Kesehatan RI; 2015.

4. Tim Riskesdas 2018. West Nusa Tenggara Basic Health Research, Provincial Riskesdas Report 2018. Jakarta: Lembaga Penerbit Badan Penelitian dan Pengembangan Kesehatan; 2019. 442 p.

5. Millennium Challenge Account Indonesia. Stunting dan Masa Depan Indonesia. Jakarta: MCA Indonesia. 2015;

6. Pérez Lizaur AB. Complementary Feeding: Report of the Global Consultation, Summary of Guiding Principles. Gac Médica México. 2011;147 Suppl(December):39-45.

7. Blaney S, Februhartanty J, Sukotjo S. Feeding practices among Indonesian children above six months of age: A literature review on their magnitude and quality (part 1). Asia Pac J Clin Nutr. 2015;24(1):16-27.

8. Abeshu MA, Lelisa A, Geleta B. Complementary Feeding: Review of Recommendations, Feeding Practices, and Adequacy of Homemade Complementary Food Preparations in Developing Countries - Lessons from Ethiopia. Front Nutr. 2016;3(October).

9. Nurbaiti L, Adi AC, Devi SR, Harthana T. Kebiasaan makan balita stunting pada masyarakat Suku Sasak: Tinjauan 1000 hari pertama kehidupan (HPK). Masy Kebud Dan Polit. 2014 Apr 1;27(2):104-12.

10. Fahmida U, Kolopaking R, Santika O, Sriani S, Umar J, Htet MK, et al. Effectiveness in improving knowledge, practices, and intakes of \&quot;key problem nutrients\&quot; of a complementary feeding intervention developed by using linear programming: experience in Lombok, Indonesia. Am J Clin Nutr. 2015;101(3):455-61.

11. Blaney S, Februhartanty J, Sukotjo S. Feeding practices among Indonesian children above six months of age: A literature review on their potential determinants (part 2). Asia Pac J Clin Nutr. 2015;24(1):28-37.

12. Complementary feeding. 2001;(December):10-3.

13. Olatona FA, Adenihun JO. Complementary Feeding Knowledge, Practices, and Dietary Diversity among Mothers of Under-Five Children in an Urban Community in Lagos State, Nigeria. 2017;6(1):46-59.

14. Rao S, Pm S, Unnikrishnan B, Hegde A, College KM. Study of complementary feeding practices among mothers of children aged six months to two years - A study from coastal south India. 2011;252-7.

15. Demilew YM, Tafere TE, Abitew DB. Infant and young child feeding practice among mothers with 0 - 24 months old children in Slum areas of Bahir Dar City ,. 2017;1-9.

16. Communication S. Short Communication A Study on Infant and Young Child Feeding Practices among Mothers Attending an Urban Health Center in East Delhi. 2012;56(4):19-22.

17. Hasnain S, Majrooh MA, Anjum R. KNOWLEDGE AND PRACTICES OF MOTHERS FOR COMPLEMENTARY FEEDING IN BABIES VISITING PEDIATRICS OUTPATIENT DEPARTMENT OF JINNAH HOSPITAL , LAHORE. :221-30.

18. Dewey KG, Adu-afarwuah S. Review Article Systematic review of the efficacy and effectiveness of complementary feeding interventions in developing countries. 2008;24-85.

19. Owais A, Suchdev PS, Schwartz B, Kleinbaum DG, Faruque ASG, Das SK, et al. Maternal knowledge and attitudes towards complementary feeding in relation to timing of its initiation in rural Bangladesh. 2019;1-8.

20. Bandara T, Hettiarachchi M, Liyanage C, Amarasena S. Current infant feeding practices and impact on growth in babies during the second half of infancy. 2015;

21. Madhu GN, Harish S. Complementary feeding practices among mothers of children aged six months to two years admitted in a tertiary care hospital. 2018;5(1):97-100.

22. Senarath U, Godakandage SSP, Jayawickrama H, Siriwardena I, Dibley MJ. Original Article Determinants of inappropriate complementary feeding practices in young children in Sri Lanka: secondary data analysis of Demographic and Health Survey 2006 - 2007. 2012;8:6077.

23. Mihretie Y. Maternal Knowledge on Complementary Feeding Practice and Nutritional Status of Children 6-23 Month in Jigjiga Town. 2018;

24. Promotion H, FoP. GUIDING PRINCIPLES FOR COMPLEMENTARY FEEDING OF THE BREASTFED. PAN AMERICAN HEALTH ORGANIZATION.

25. Seram SN V, Punchihewa PMG. Knowledge on complementary feeding among parents of children aged 4-12 months attending a base hospital in a rural district in Sri Lanka. 2017;46(2):139-47.

26. Karigi LN, Mutuli LA. Socio-cultural practices and beliefs influencing infant and young child feeding in lubao sub-location Kakamega Country. 2016;5(1):568-71.

Page $16 / 20$ 
27. Berhanu Z, Alemu T, Argaw D. Predictors of inappropriate complementary feeding practice among children aged 6 to 23 months in Wonago District, South Ethiopia , 2017; case control study. 2019;1-13.

28. Gebremedhin S, Baye K, Bekele T, Tharaney M, Asrat Y, Sc M, et al. Predictors of dietary diversity in children 6-23 months of age in largely food insecure area of South Wollo, Ethiopia. Nutrition. 2016;

29. Hotz C, Gibson RS. Participatory nutrition education and adoption of new feeding practices are associated with improved adequacy of complementary diets among rural Malawian children: a pilot study. Eur J Clin Nutr. 2005 Feb;59(2):226-37.

30. Shi L, Zhang J, Wang Y, Caulfield LE, Guyer B. Effectiveness of an educational intervention on complementary feeding practices and growth in rural China: a cluster randomised controlled trial. Public Health Nutr. 2010 Apr;13(4):556-65.

\section{Figures}
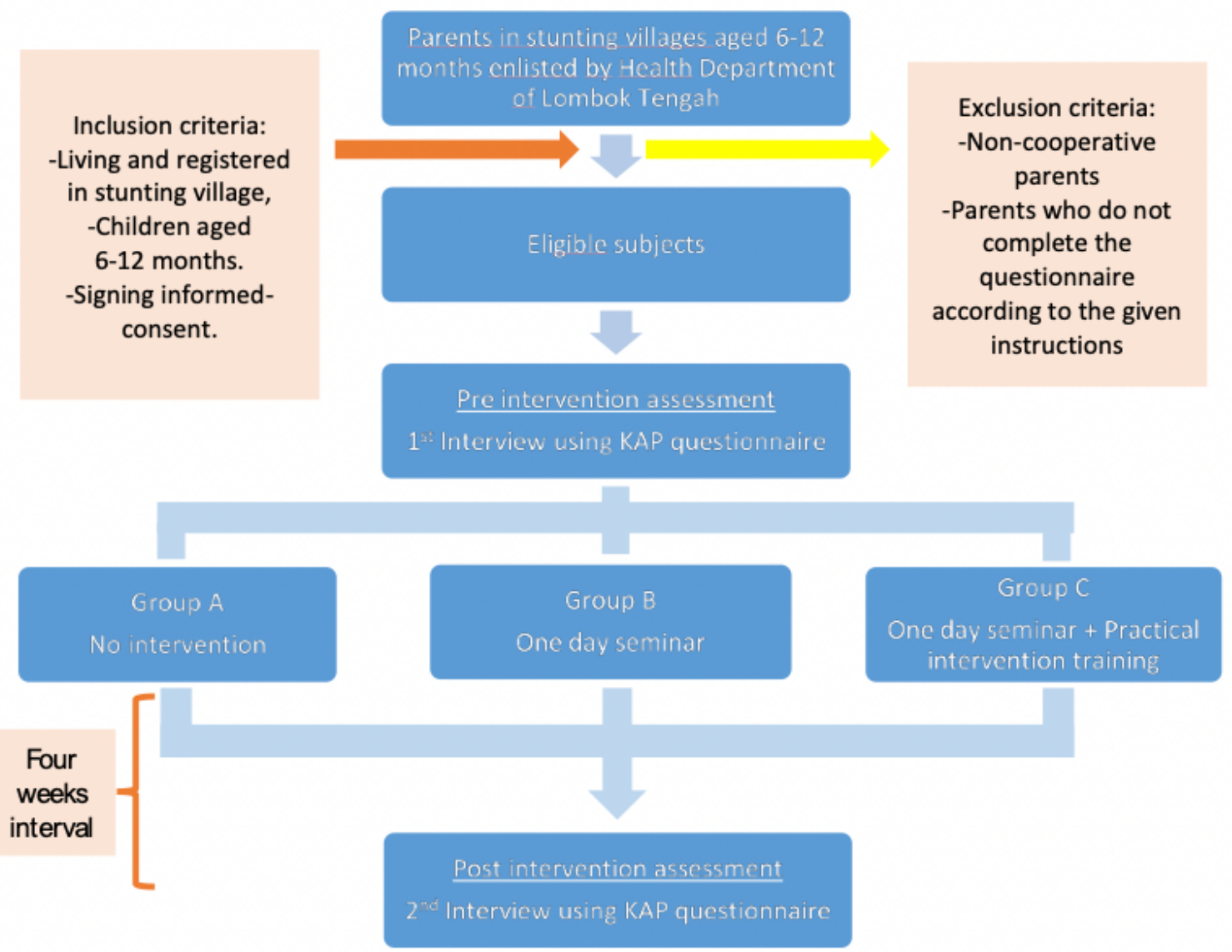

Figure 1

Research protocol overview 


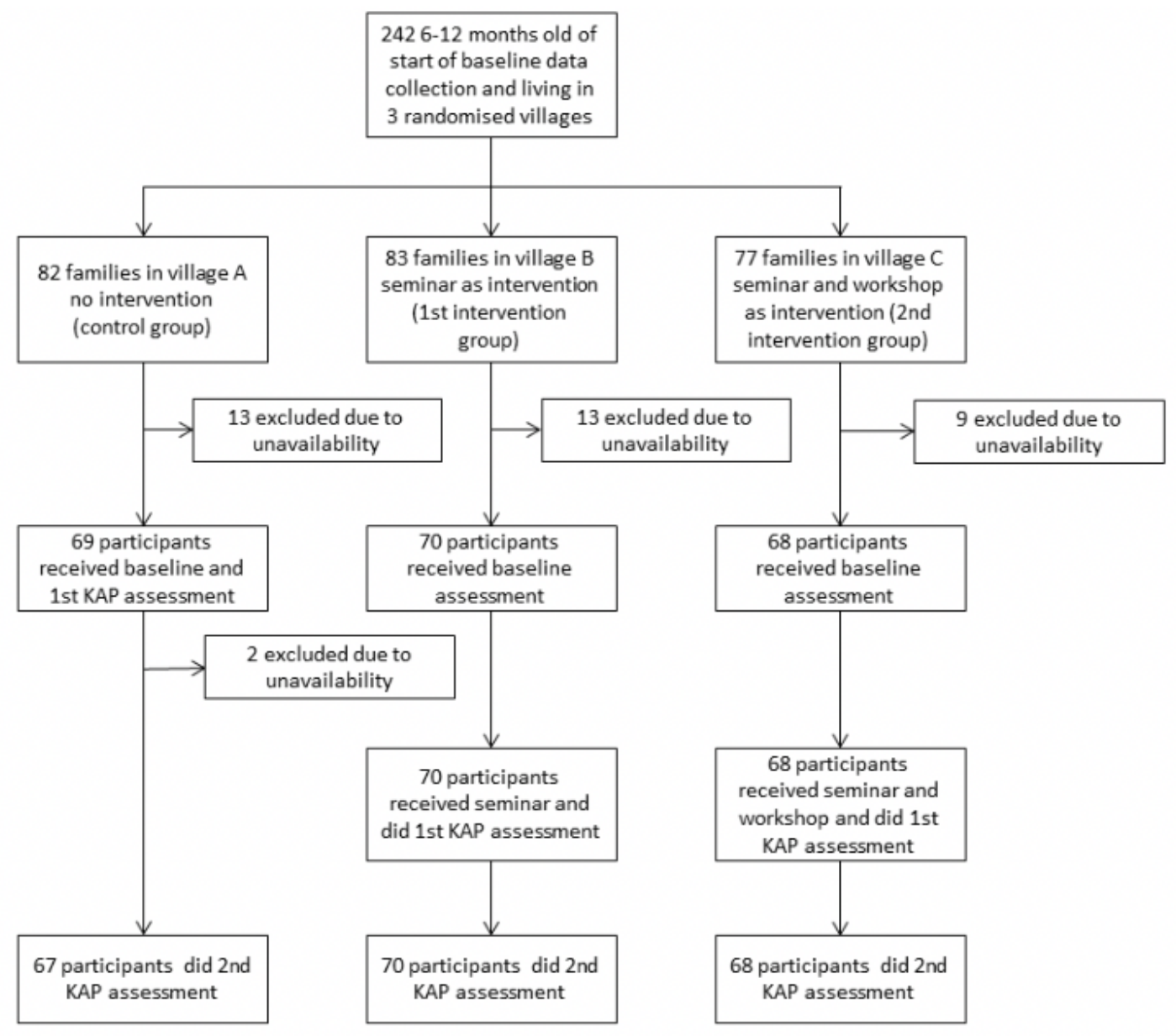

Figure 2

Trial profile of the study 


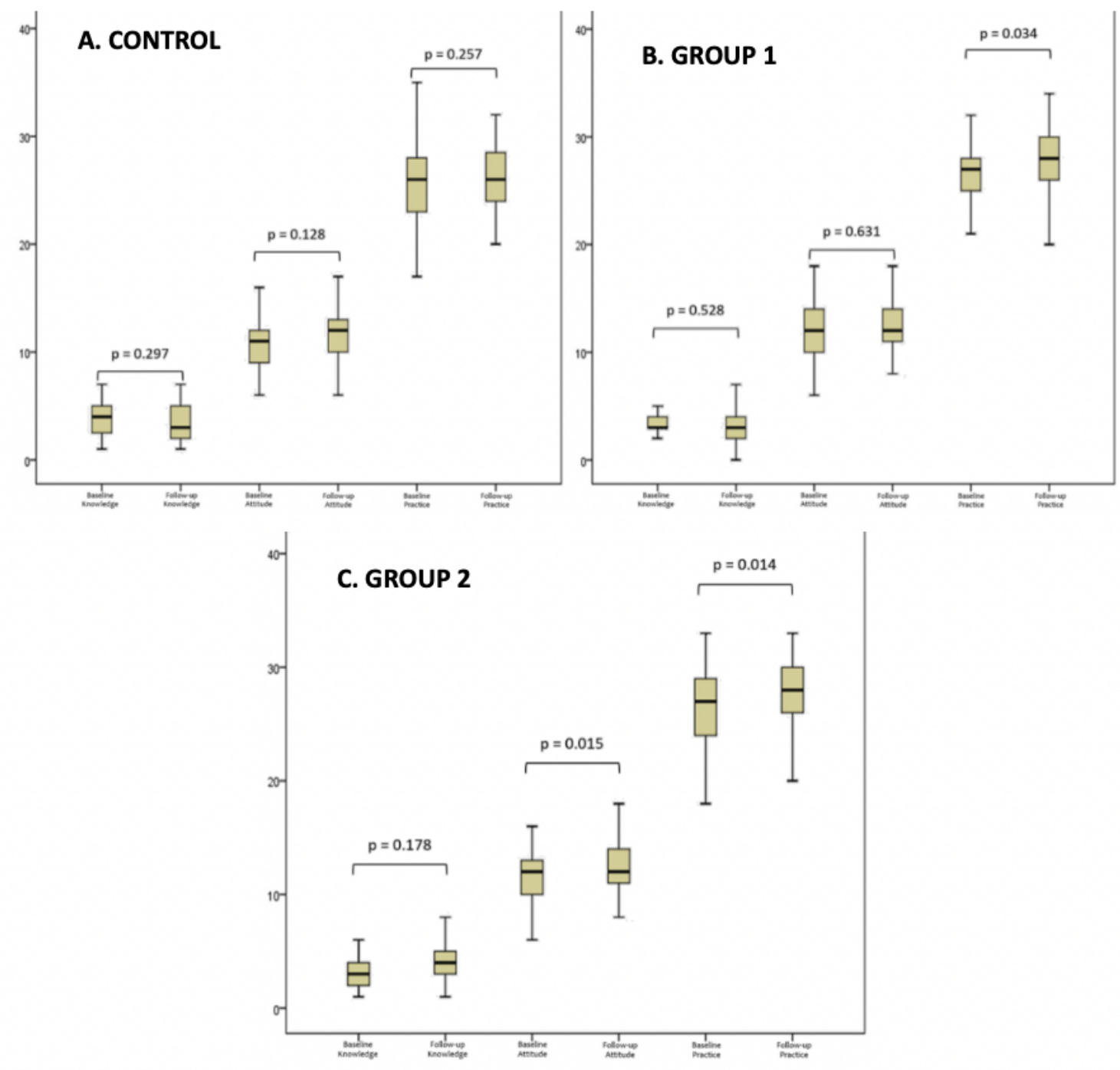

Figure 3

Difference between baseline and follow-up knowledge, attitude, and practice: A) in control group; B) in seminar intervention group (Group 1); and C) in complete (seminar and workshop) intervention group (Group 2) 

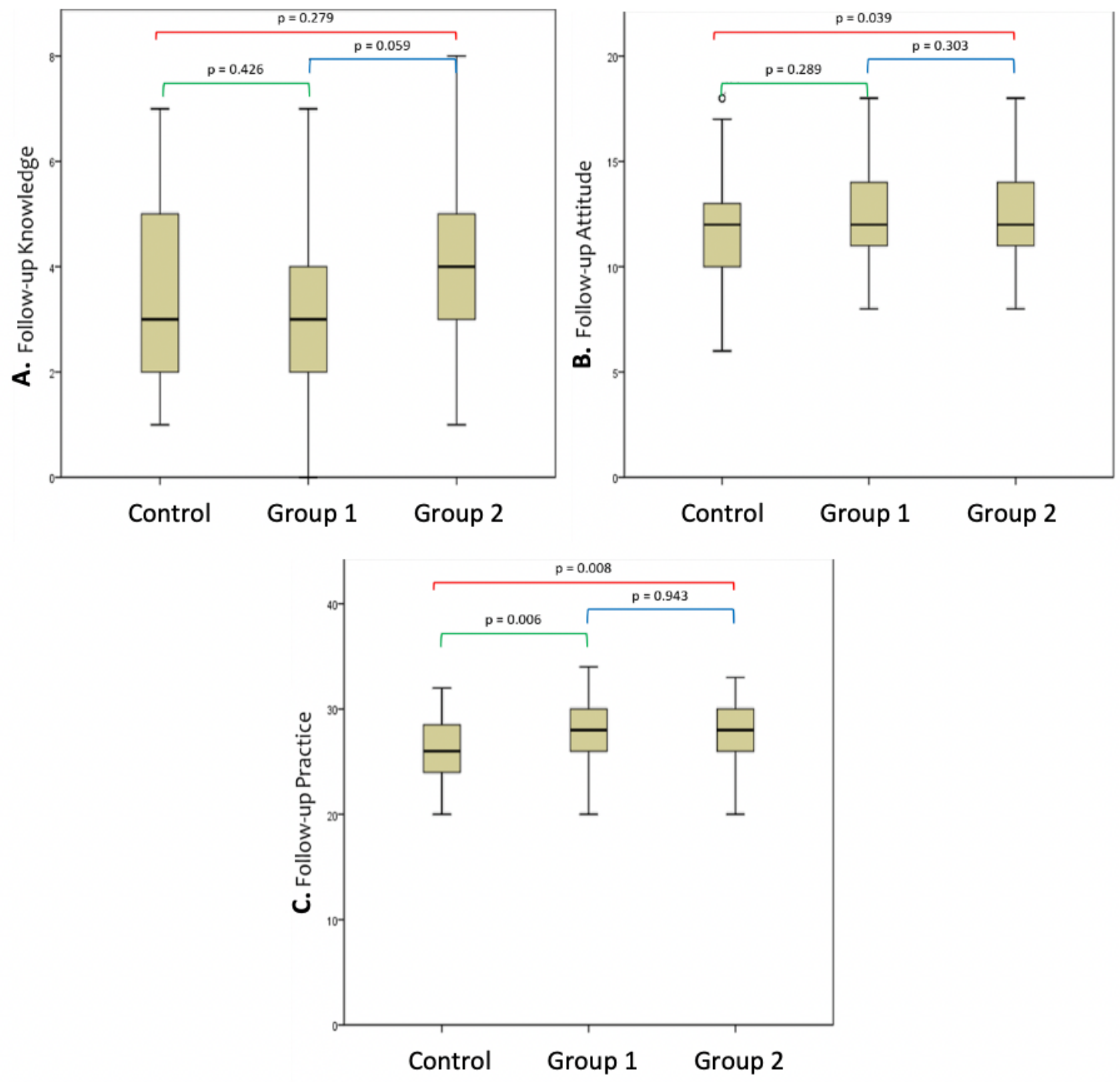

\section{Figure 4}

Knowledge (A), attitude (B), and practice (C) difference between control and interventions groups (Group 1 and Group 2)

\section{Supplementary Files}

This is a list of supplementary files associated with this preprint. Click to download.

- BMCAdditionalfile2.docx

- BMCAdditionalfile1.docx 